\title{
Effects of energy density in close-up diets and postpartum supplementation of extruded full-fat soybean on lactation performance and metabolic and hormonal status of dairy cows
}

\author{
Qian Zhang, ${ }^{1}$ Huawei Su, ${ }^{1}$ Fuwei Wang, Zhijun Cao, ${ }^{2}$ and Shengli $\mathrm{Li}^{2}$ \\ State Key Laboratory of Animal Nutrition, College of Animal Science and Technology, China Agricultural University, Beijing 100193, China
}

\begin{abstract}
This experiment was conducted to investigate the effect of energy density (ED) in the close-up period and supplementation of extruded full-fat soybean (ESB) during the first 4 wk after parturition on intake, body weight (BW), metabolic status, and performance of dairy cows. Fifty-seven Chinese Holstein cows with similar parity, previous 305-d milk yield, and expected calving date were dried off at $-60 \mathrm{~d}$ relative to parturition and fed the standard herd dry-cow diet until $-21 \mathrm{~d}$ relative to parturition. Energy density at low (LED, 1.25 Mcal $/ \mathrm{kg}$ ), medium (MED, $1.41 \mathrm{Mcal} / \mathrm{kg}$ ) or high (HED, $1.55 \mathrm{Mcal} / \mathrm{kg}$ ) levels of the close-up diets and postpartum supplementation of ESB at $0 \mathrm{~kg} / \mathrm{d}$ (control, CON) or $1.5 \mathrm{~kg} / \mathrm{d}$ (TRT) were used in a 3 $\times 2$ factorial arrangement. All cows received the same CON diet from wk 5 to wk 8. As ED increased in the close-up diet, cows had higher dry matter intake and gained more BW and body condition score, and consequently were in improved energy balance status during the prepartum period, but lost more $\mathrm{BW}$ and more body condition score during the first 8 wk of lactation. Compared with LED cows, HED cows had higher blood concentrations of insulin and glucose, and lower nonesterified fatty acids (NEFA) prepartum, but had lower insulin concentration, higher leptin concentration and tended to have higher NEFA concentration postpartum. Milk production was not affected by the prepartum ED, although HED cows produced approximately $2 \mathrm{~kg} / \mathrm{d}$ less milk than MED and LED cows during early lactation. Postpartum ESB supplementation elevated blood glucagon concentration regardless of prepartum ED during the first $4 \mathrm{wk}$ of lactation. Interactive effects between prepartum ED and postpartum ESB
\end{abstract}

Received November 15, 2014.

Accepted June 16, 2015.

${ }^{1}$ These authors contributed equally to the research.

${ }^{2}$ Corresponding authors: caozhijun@cau.edu.cn and lisheng0677 @163.com supplementation were observed in blood concentrations of insulin, NEFA, bilirubin, total protein, albumin, and globulin. During early lactation, TRT decreased globulin concentrations in MED cows, and reduced NEFA and bilirubin concentrations in HED cows. Compared with CON, TRT cows had higher yields of milk (34.32 vs. $36.53 \mathrm{~kg} / \mathrm{d}$ ), milk lactose (1.63 vs. $1.74 \mathrm{~kg} / \mathrm{d}$ ), and solids-nonfat (2.98 vs. $3.18 \mathrm{~kg} / \mathrm{d})$, tended to have a greater yield of milk protein (1.11 vs. $1.17 \mathrm{~kg} / \mathrm{d})$, but tended to have lower milk fat percentage (4.18 vs. $3.94 \%$ ) during the first $4 \mathrm{wk}$ of lactation. In conclusion, compared with feeding the HED diet, feeding the LED diet during the close-up dry period had positive carryover effects on metabolism and production during early lactation, and the MED diet showed no advantage over the LED diet. Extruded full-fat soybean supplementation during the first $4 \mathrm{wk}$ of lactation had positive effects on postpartum metabolic status, especially for those receiving the MED or HED diet prepartum, and resulted in an overall improved milk production during early lactation.

Key words: transition period, prepartum energy intake, extruded full-fat soybean

\section{INTRODUCTION}

The transition from late gestation to early lactation is the most metabolically challenging time for dairy cattle (Grummer, 1995; Goff and Horst, 1997; Drackley, 1999). Up to $75 \%$ of diseases in dairy cattle occur in the first month after parturition (LeBlanc et al., 2006). The dramatic increase in nutrient requirements to support the onset of lactation often cannot be met by dietary intake of dairy cows during early lactation, causing them to experience negative energy balance (EB) and negative nutrient balance during early lactation (Baracos et al., 1991; Bell, 1995). Earlier strategies focused on feeding energy-dense diets and maximizing DMI prepartum, and aimed at supporting development of the conceptus and mammary gland, and preparing dry cows for better adaptation to the early-lactation 
diet (Vandehaar et al., 1999; Mashek and Beede, 2001; Rabelo et al., 2001). In the past 15 yr, this theory has been greatly challenged, and dairy cows overfed prepartum have been shown to experience more severe negative EB, have greater mobilization of FA from body adipose tissue, and be more prone to development of metabolic disorders postpartum (Agenäs et al., 2003; Douglas et al., 2006; Janovick et al., 2011).

Many research studies have controlled prepartum energy consumption by feed restriction (Agenäs et al., 2003; Douglas et al., 2006; Winkelman et al., 2008). Considering the difficulty in restricting feed intake on farm, other studies have controlled prepartum energy intake by including a higher percentage of low quality forages in the diet (Beever, 2006; Vickers et al., 2013). More research is needed to investigate how controlling prepartum energy intake through diet formulation affects metabolism and performance of dairy cows in the upcoming lactation.

Full-fat soybeans have been used in the rations of high-yielding dairy cows as a source of both energy and protein (Chouinard et al., 1997). The heating and extruding treatments for processing extruded full-fat soybean (ESB) increase proportions of undegradable protein (Faldet and Satter, 1991), and a diet containing ESB was shown to have an increased amount of total EAA available in the small intestine and increased absorption of AA from the small intestine (Stern et al., 1985). Effects of feeding ESB on lactation performance have been inconsistent. Despite the variation in sources, processing, and feeding conditions of ESB, state of lactation seems an important factor that influences the response of feeding ESB on performance. Increased milk yield and milk protein were observed by feeding ESB to early-lactation dairy cows (Smith et al., 1980; Ruegsegger and Schultz, 1985). In contrast, no effects of feeding ESB on milk production and composition were observed in cows that were past peak production (Mielke and Schingoethe, 1981; Annexstad et al., 1987). Despite the extensive investigation into the effects of ESB on lactation performance, limited data are available to evaluate the effects of ESB on the metabolic responses of early-lactation cows.

In this study, we speculate that an interaction occurs between prepartum energy intake and postpartum ESB supplementation on metabolism and production of dairy cows during early lactation. We hypothesized that ad libitum feeding of a lower energy density (ED) diet during the close-up period and supplement of ESB postpartum would improve metabolic status and performance of dairy cows during early lactation. The objective was to test the effects of 3 prepartum diets differing in ED and postpartum supplementation of
ESB for 4 wk on DMI, BCS, EB, metabolic status, and lactation performance of dairy cows.

\section{MATERIALS AND METHODS}

\section{Experimental Design and Cow Management}

Animals were cared for in accordance with the practices outlined in the Guide for the Care and Use of Agricultural Animals in Research and Teaching (FASS, 2010).

Sixty multiparous Chinese Holstein cows with similar BW, parity, previous 305-d milk yield, and expected calving date at a commercial dairy herd located in northern China were used from $60 \mathrm{~d}$ before projected calving until 56 DIM. Three cows were subsequently excluded from the experiment because of early or late calving. Cows were moved to a tiestall barn at $21 \mathrm{~d}$ before the expected calving date until the end of the experiment. After parturition, cows were milked daily at 0430,1130 , and $1830 \mathrm{~h}$. Cows had free access to water throughout the experiment.

Cows were dried off at $-60 \mathrm{~d}$ relative to expected parturition and fed the standard herd far-off diet (Table 1) for ad libitum intake until $-21 \mathrm{~d}$ relative to parturition. Cows were then randomly assigned to 1 of 3 close-up diets: low ED diet $\left(\mathbf{L E D} ; \mathrm{NE}_{\mathrm{L}}=1.25\right.$ $\mathrm{Mcal} / \mathrm{kg}$ of DM), medium ED diet (MED; $\mathrm{NE}_{\mathrm{L}}=1.41$ $\mathrm{Mcal} / \mathrm{kg}$ of DM), or high ED diet (HED; $\mathrm{NE}_{\mathrm{L}}=1.55$ Mcal/kg of DM) until parturition (Table 1). The actual days that cows were on the prepartum treatments were $23.3 \pm 4.0$ d. After calving, cows within each ED group were randomly assigned to receive either a control diet (CON) to meet lactation requirements according to NRC (2001) or a treatment diet (TRT) supplemented with $1.5 \mathrm{~kg} / \mathrm{d}$ of ESB (accounting for $7.2 \%$ of dietary DM) during the first 4 wk of lactation (Table 1). The ESB contained $91.0 \%$ DM, $38.7 \% \mathrm{CP}$, and $20.6 \%$ ether extract on a DM basis. All animals received the same lactation diet as CON from wk 5 to 8 . Both the prepartum and lactation diets were fed as a TMR for ad libitum intake at 0500,1200 , and 1900 h daily to achieve 5 to $10 \%$ refusals.

\section{Data Collection and Sampling and Analytical Procedures}

Feed intake of each cow was recorded daily and DMI was determined by difference of feed offered and refused and adjusted for feed DM content. Samples of TMR, concentrate, corn silage, corn stover, alfalfa, and Chinese wildrye hay were collected once per week and analyzed for chemical composition. The method 
Table 1. Diet ingredients and nutrient composition during dry period and early lactation

\begin{tabular}{|c|c|c|c|c|c|c|}
\hline Item & Far-off $^{1}$ & \multicolumn{3}{|c|}{ Close-up ${ }^{2}$} & \multicolumn{2}{|c|}{ Early lactation $^{3}$} \\
\hline \multicolumn{7}{|l|}{ Ingredient, $\%$ of $\mathrm{DM}$} \\
\hline Corn silage & - & - & 19.9 & 36.5 & 22.4 & 20.8 \\
\hline Chinese wildrye & 27.6 & 27.0 & 24.9 & 22.9 & 8.3 & 7.6 \\
\hline Alfalfa hay & - & 16.1 & 7.5 & - & 12.6 & 11.7 \\
\hline Soybean meal & 2.5 & 2.5 & 3.1 & 2.8 & 6.1 & 5.7 \\
\hline Cottonseed meal & 1.8 & 2.6 & 3.0 & 2.4 & 4.6 & 4.3 \\
\hline Rapeseed meal & 1.3 & 2.0 & 3.0 & 2.4 & 2.5 & 2.4 \\
\hline Brewers grains & - & - & - & - & 5.7 & 5.3 \\
\hline Dried distillers grains with solubles & 3.0 & 1.5 & 2.2 & 2.4 & 5.1 & 4.7 \\
\hline $\mathrm{ESB}^{4}$ & - & - & - & 3.2 & - & 7.2 \\
\hline Premix ${ }^{5}$ & 1.3 & 1.2 & 1.3 & 1.4 & 2.5 & 2.4 \\
\hline $\mathrm{CP}$ & 11.19 & 13.00 & 13.14 & 13.06 & 17.01 & 18.57 \\
\hline Ether extract & 2.56 & 2.35 & 3.13 & 3.44 & 4.22 & 5.40 \\
\hline $\mathrm{NDF}$ & 54.87 & 56.25 & 49.88 & 43.50 & 41.11 & 39.85 \\
\hline $\mathrm{ADF}$ & 32.11 & 32.52 & 27.91 & 22.94 & 20.72 & 20.12 \\
\hline $\mathrm{NFC}^{9}$ & 21.97 & 20.63 & 26.92 & 33.68 & 30.01 & 28.63 \\
\hline Ash & 9.41 & 8.77 & 7.34 & 6.32 & 7.33 & 7.25 \\
\hline $\mathrm{Ca}$ & 0.68 & 0.75 & 0.70 & 0.63 & 0.95 & 0.90 \\
\hline $\mathrm{P}$ & 0.29 & 0.33 & 0.37 & 0.39 & 0.46 & 0.47 \\
\hline
\end{tabular}

${ }^{1}$ Diet fed from 60 to $22 \mathrm{~d}$ before parturition.

${ }^{2}$ Diets fed from $21 \mathrm{~d}$ before parturition until calving; LED = low energy density, MED = medium energy density, and HED = high energy density.

${ }^{3}$ Diets fed during first $4 \mathrm{wk}$ of lactation; $\mathrm{CON}=$ control lactation diet fed ad libitum to meet lactation requirement during early lactation; TRT $=$ treatment diet supplemented with $1.5 \mathrm{~kg} / \mathrm{d}$ of extruded full-fat soybean.

${ }^{4}$ Extruded full-fat soybean, containing $91.0 \%$ DM, 38.7\% CP, $20.6 \%$ ether extract, $23.6 \%$ NDF, $12.4 \%$ ADF, $6.20 \%$ ash, $0.26 \%$ Ca, and $0.61 \%$ $\mathrm{P}$ on DM basis.

${ }^{5}$ Premix for dry cows: $1 \mathrm{~kg}$ of premix included vitamin A 440,000 IU, vitamin $\mathrm{D}_{3}$ 110,000 IU, vitamin E 4,000 IU, niacin $400 \mathrm{mg}$, Ca $152 \mathrm{~g}$, P 41g, Cu $750 \mathrm{mg}$, Mn 1,140 mg, Zn 2,970 mg, I $30 \mathrm{mg}$, Se $36 \mathrm{mg}$, and Go $24 \mathrm{mg}$. Premix for early-lactation cows: $1 \mathrm{~kg}$ premix included vitamin A 154,000 IU, vitamin $\mathrm{D}_{3}$ 38,500 IU, vitamin E 1,400 IU, niacin $140 \mathrm{mg}$, Ca $161 \mathrm{~g}, \mathrm{P} 32 \mathrm{~g}, \mathrm{Cu} 550 \mathrm{mg}$, Mn $840 \mathrm{mg}$, Zn 2,180 mg, I $22 \mathrm{mg}$, Se $26 \mathrm{mg}$, and Go $18 \mathrm{mg}$.

${ }^{6}$ Calcium salts of long-chain fatty acids (Volac Ltd., Royston, UK).

${ }^{7}$ Measured from laboratory analysis of TMR.

${ }^{8}$ Calculated according to NRC (2001).

${ }^{9} \mathrm{NFC}=100-(\% \mathrm{NDF}+\% \mathrm{CP}+\%$ fat $+\%$ ash $)$.

described by AOAC International (2000) was used for analysis of DM, CP, ADF, ether extract, ash, calcium, and phosphorus. The content of NDF was analyzed following Van Soest et al. (1991) using heat-stable

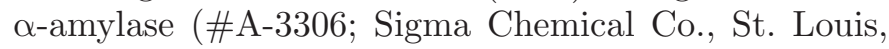
MO) for the Ankom 200 fiber analyzer (Ankom Technology, Fairport, NY).

Body weight and BCS of the cows were measured after the morning milking and before the morning feeding at $-21,-14,-7,+1,+7,+14,+21,+28,+42$ and $+56 \mathrm{~d}$ relative to calving. Body condition score was evaluated independently by 3 individuals according to the method of Wildman et al. (1982) and averaged for each cow. Both prepartum and postpartum EB was calculated individually for each cow using equations from NRC (2001). Net energy intake ( $\mathbf{N E}_{\mathbf{I}}$, Mcal) was calculated by multiplying the daily DMI by the mean $\mathrm{NE}_{\mathrm{L}}$ density of the diet. Net energy for maintenance $\left(\mathrm{NE}_{\mathrm{M}}\right.$, Mcal) was calculated as $\mathrm{BW}^{0.75} \times 0.08$. Net energy requirement for pregnancy $\left(\mathbf{N E}_{\mathbf{P}}\right.$, Mcal) was calculated as $[(0.00318 \times$ day of gestation -0.0352$) \times$ (calf birth weight/45)]/0.218. Net energy requirement for lactation $\left(\mathrm{NE}_{\mathrm{L}}, \mathrm{Mcal}\right)$ was calculated as $(0.0929 \times$ fat $\%+0.0547 \times$ protein $\%+0.0395 \times$ lactose $\%)$ $\times$ milk yield. Prepartum EB was calculated using the equation $\mathrm{EB}=\mathrm{NE}_{\mathrm{I}}-\left(\mathrm{NE}_{\mathrm{M}}+\mathrm{NE}_{\mathrm{P}}\right)$; and postpartum $\mathrm{EB}$ was calculated using the equation $\mathrm{EB}=\mathrm{NE}_{\mathrm{I}}-$ $\left(\mathrm{NE}_{\mathrm{M}}+\mathrm{NE}_{\mathrm{L}}\right)$. 
Milk samples from each cow were collected weekly from 7 through 56 DIM. During each collection day, $50 \mathrm{~mL}$ of milk was mixed at a ratio of $4: 3: 3$ of the 3 milkings from each cow. One aliquot was analyzed for contents of protein, fat, lactose, SNF, and SCC using a near-infrared reflectance spectroscopy analyzer (Seris300 CombiFOSS; Foss Electric, Hillerød, Denmark) at the Beijing Dairy Cattle Center. A second aliquot was deproteinized (Ekinci and Broderick, 1997) and analyzed for MUN by colorimetric assay.

Blood samples were collected from the coccygeal vessel into evacuated tubes $4 \mathrm{~h}$ after morning feeding at $-21,-14,-7,+1,+7,+14,+21,+28,+42$ and $+56 \mathrm{~d}$ relative to calving. Tubes containing heparin were used for plasma collection, and serum separator tubes were used for serum collection. Tubes for plasma preparation were put on ice immediately after sampling and centrifuged at $4^{\circ} \mathrm{C}$ at $3,000 \times g$ for $20 \mathrm{~min}$. Tubes for serum preparation were allowed to clot for $30 \mathrm{~min}$ at room temperature before centrifugation for $15 \mathrm{~min}$ at 1,000 $\times$ $g$ at $4^{\circ} \mathrm{C}$. Plasma and serum were aliquoted into $1.5-\mathrm{mL}$ centrifuge tubes and stored at $-20^{\circ} \mathrm{C}$ pending analysis. Plasma samples were sent to a clinical laboratory of the 309th Hospital (Beijing, China) for analyzing glucose, NEFA, BUN, triglyceride, total protein, albumin, and total bilirubin using an auto-analyzer (ILAB 600, Instrumentation Laboratory, Lexington, MA) with kits supplied by Instrumentation Laboratory. Plasma concentrations of BHBA were measured using a BHBA kit (Sigma Chemical Co.). Globulin was calculated by subtracting albumin from the total protein. Radioimmunoassay kits were used to measure serum insulin (Coat-A-Count Insulin, Siemens Medical Solutions USA Inc., Malvern, PA) and plasma glucagon (Double Antibody Glucagon, Siemens Medical Solutions USA Inc.). Serum leptin concentration was measured with a RIA-method described previously (Delavaud et al., 2000, 2002).

\section{Statistical Analyses}

Before statistical analysis, daily measurements of DMI and milk yield were calculated for weekly means. Energy-corrected milk was calculated using the equation $(0.327 \times$ milk yield $)+(12.95 \times$ milk fat yield $)+$ $(7.20 \times$ milk protein yield) (Tyrrell and Reid, 1965) Analyses of variance of the data were performed using Proc Mixed of SAS 9.2 (SAS Institute Inc., Cary, NC). Prepartum and postpartum data were analyzed separately. For analyzing prepartum data, the model included the fixed effects of ED, time, ED $\times$ time interaction, and random effect of cow. For analyzing postpartum data, the model included the fixed effects of prepartum ED, postpartum ESB supplementation, time, $\mathrm{ED} \times \mathrm{ESB}$ interaction, $\mathrm{ED} \times$ time interaction, $\mathrm{ESB} \times$ time interaction, $\mathrm{ED} \times \mathrm{ESB} \times$ time interaction, and random effect of cow. For both prepartum and postpartum data, when analyzing changes in BW and BCS, the fixed effects of time and associated interactions were excluded from the above models. All variables except the changes in BW and BCS were analyzed using repeated measures with the spatial power covariance structure model. Tukey-Kramer studentized adjustments were used to separate treatment means when main effects were significant. Data are reported as least squares means \pm standard error of the means $(\mathrm{LSM} \pm \mathrm{SEM})$. Significance was declared at $P<0.05$ and tendencies when $0.05 \leq P \leq 0.10$.

\section{RESULTS AND DISCUSSION}

\section{Prepartum Weeks -3 to -1}

DMI, $\boldsymbol{B} \boldsymbol{C S}$, and $\boldsymbol{E B}$. At -21 d relative to expected calving date, cows assigned to the different dietary treatments did not differ in parity $(2.2 \pm 0.1)$, previous lactation 305-d mature-equivalent milk yield $(7,821.5$ $\pm 70.5 \mathrm{~kg})$, BCS $(3.53 \pm 0.05)$, or BW $(700.5 \pm 10.5$ $\mathrm{kg})$. In this experimental design, prepartum dietary treatments were formulated to contain different levels of calculated $\mathrm{NE}_{\mathrm{L}}$ and balanced for all other nutrients. Therefore, the potential effects of difference in intake of other nutrients due to different DMI cannot be separated from the major effect of $\mathrm{ED}$

During the close-up period, DMI of cows in LED $(9.84 \mathrm{~kg} / \mathrm{d}), \operatorname{MED}(11.88 \mathrm{~kg} / \mathrm{d})$, and HED $(14.32 \mathrm{~kg} / \mathrm{d})$ was affected by dietary treatments $(P<0.0001$; Table $2)$. As ED in the formulated close-up diets decreased, DMI decreased, mainly because of the high inclusion rate of corn stover that increased NDF concentration. Accordingly, calculated energy intakes of cows in LED, MED, and HED were different $(P<0.0001)$, supplying 88,120 , and $157 \%$ of $\mathrm{NE}_{\mathrm{L}}$ requirement for dry cows during late gestation (NRC, 2001) respectively (Table $2)$. Changes in BW $(P<0.0001)$ and BCS $(P=0.03)$ were both affected by dietary treatments (Table 2). All cows gained BW as expected, with increased fetal growth during late pregnancy, and the increase in BW was greater in HED than in MED, which was greater than that in LED. The LED cows lost 0.05 units of BCS, whereas MED cows and HED cows increased BCS by 0.04 and 0.12 units, respectively. This coincides with the EB of the groups, with LED cows being in slightly negative EB and the MED and HED cows being in positive EB (Table 2). Increased BCS by overfeeding energy prepartum was commonly observed in previ- 
PREPARTUM ENERGY LEVEL AND POSTPARTUM SOYBEAN FEEDING

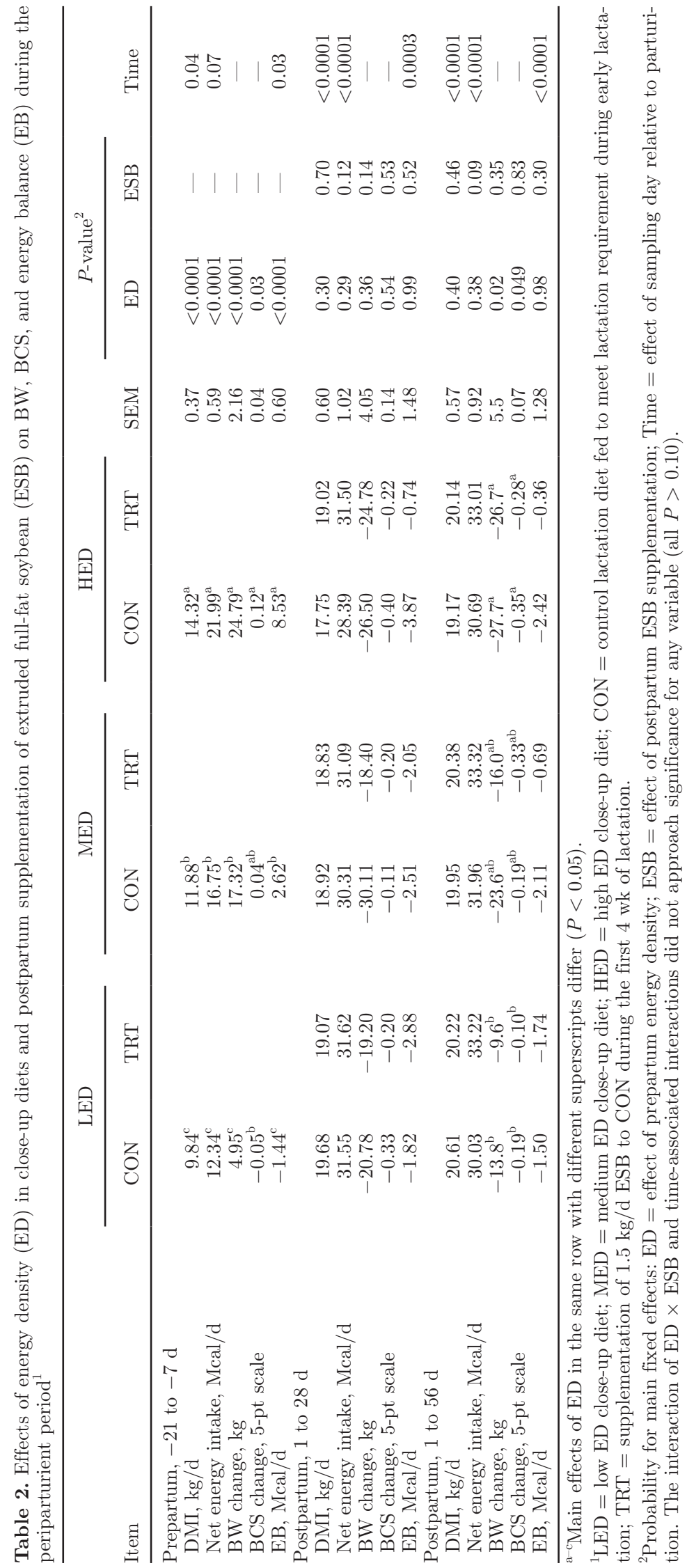


ous studies (Vandehaar et al., 1999; Dann et al., 2006; Douglas et al., 2006).

Blood Hormones and Metabolites. Concentrations of serum insulin (Figure 1) and plasma glucose (Figure 2$)$ were elevated $(P<0.01)$ in HED cows compared with LED cows. Cows in the HED group had increased intake of a higher ED diet with a greater amount of fermentable starch-rich sources that supplied more gluconeogenic precursors, particularly propionate for glucose production in liver. Elevated blood glucose and insulin concentrations in response to greater DMI and energy intake prepartum were reported by others (Holtenius et al., 2003; Douglas et al., 2006). A treatment by time interaction $(P<0.0001)$ was detected for plasma NEFA concentration (Figure 2). Compared with LED cows, MED and HED cows had lower $(P<$ $0.0001)$ NEFA concentrations at -14 and $-7 \mathrm{~d}$ relative to parturition. Plasma NEFA concentration of LED cows was greater than $0.3 \mathrm{mEq} / \mathrm{L}$ at $-7 \mathrm{~d}$, which exceeded the critical threshold of prepartum NEFA that is associated with greater risk for development of postpartum disease such as metritis and retained placenta (Ospina et al., 2010). The lower NEFA concentration in MED and HED cows compared with LED cows was because of higher energy intake and improved EB, which subsequently reduced fat mobilization. Decreased blood NEFA concentration prepartum is commonly observed when prepartum energy intake is increased (Hayirli et al., 2011). Janovick et al. (2011) demonstrated that cows overfed to meet $150 \%$ of the NRC energy requirement had lower NEFA concentration compared with cows restricted fed to meet $80 \%$ of the NRC requirement and cows fed ad libitum high forage diet to meet $100 \%$ of the NRC requirement. Plasma BHBA concentration was affected $(P<0.05)$ by dietary treatments, with a higher $(P<0.01)$ concentration in MED and HED cows compared with LED cows (Figure 2). A lower BHBA level with MED and HED would be expected given the lower NEFA and higher concentrations of insulin, a hormone that represses ketogenesis (Hayirli, 2006). Several studies indicate that prepartum BHBA is not altered by increased energy intake prepartum, along with decreased NEFA and elevated insulin concentrations (Douglas et al., 2006; Hayirli et al., 2011; Janovick et al., 2011). However, BHBA concentrations of all cows in the present study were within the range reported by others (Douglas et al., 2006; Hayirli et al., 2011; Janovick et al., 2011). Additionally, the concentrations of prepartum NEFA and postpartum NEFA and BHBA, but not prepartum BHBA, are usually considered important indicators to evaluate health condition and predict disease occurrence during the periparturient period (Ospina et al., 2010).
Concentrations of leptin were not affected $(P>0.10)$ by prepartum ED. Leptin concentration increased from d -21 to -14 and then decreased around parturition. Reduction of leptin concentration around parturition is consistent with previous reports in dairy cows (Kadokawa et al., 2000; Block et al., 2001; Liefers et al., 2003); the reduction may be necessary for stimulating hyperphagia to support upcoming lactation (Liefers et al., 2003). Leptin plays an important role in regulation of feed intake and energy metabolism and is positively related to DMI, EB, and insulin concentration (Liefers et al., 2003; Reist et al., 2003), as well as prepartum feeding level (Holtenius et al., 2003; Hayirli et al., 2011; Janovick et al., 2011). Despite significant differences in DMI, EB, and insulin among dietary treatment groups, prepartum leptin concentrations were not different in the present study. The reason for this inconsistency with previous work is not readily apparent. One possibility is that the genetic background of these Chinese Holstein cows was different from those used in the previous work. In the mixed-effects model generated by Reist et al. (2003) to evaluate the relationship between leptin and various factors such as DMI, BCS, EB, and insulin, individual cows account for most of the variance in the model. As suggested by Liefers et al. (2003), genetic component may play an important role in circulating leptin concentrations.

\section{Postpartum Weeks 1 to 8}

$D M I, B S C$, and $\boldsymbol{E B}$. No interaction between prepartum ED and postpartum ESB supplementation was detected for DMI, BCS, BW, or EB $(P>0.10)$. Prepartum ED did not affect $(P>0.10)$ DMI during early lactation (Figure 3). Unaffected postpartum DMI by feeding level in the close-up period has been reported previously (Holcomb et al., 2001; Dann et al., 2006). All cows decreased BW and BCS after parturition (Figure 3 ). The magnitudes of loss in BW and BCS were not different $(P>0.10)$ among prepartum ED treatments during the first 4 wk of lactation but were different $(P$ $<0.01)$ during the first 8 wk of lactation. Cows in the HED group lost more BW $(P=0.02)$ and BCS $(P=$ 0.049 ) than cows in the LED group over the first $8 \mathrm{wk}$ of lactation, which is attributed to the fact that LED cows, but not HED cows, started to gain BW and BCS from 5 to 8 wk of lactation (Table 2; Figure 3). This is in agreement with a previous study that compared cows underfed to supply $80 \%$ of energy requirement with cows overfed to supply $150 \%$ of energy requirement; the overfed cows lost more BW and BCS during the first $8 \mathrm{wk}$ of lactation even though postpartum DMI between the 2 groups was not different (Janovick and 

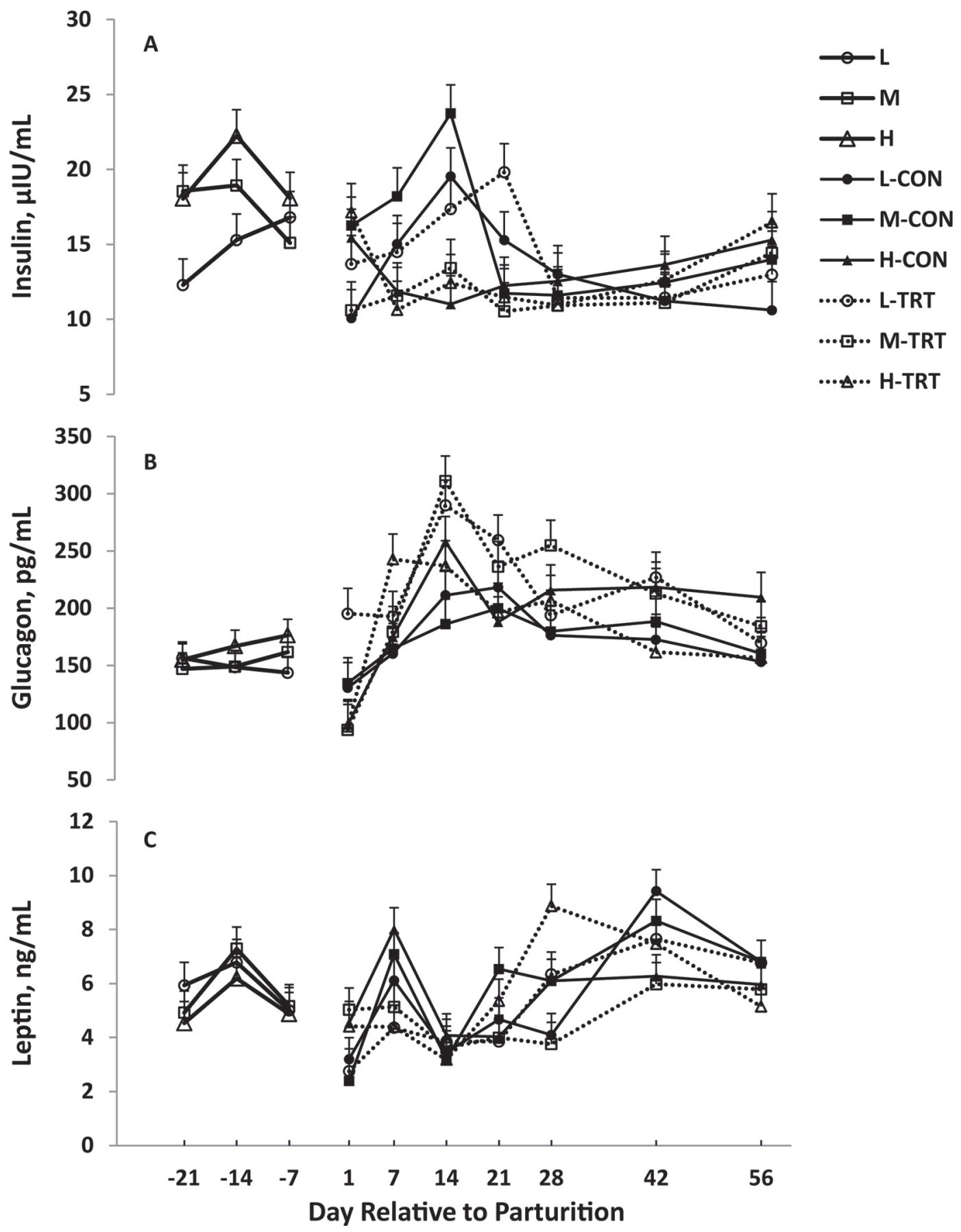

Figure 1. Effects of energy density (ED) in close-up diets and postpartum supplementation of extruded full-fat soybean (ESB) on blood insulin (A), glucagon (B), and leptin (C) concentrations during the periparturient period. L = low ED close-up diet; $\mathrm{M}=$ medium ED close-up diet; $\mathrm{H}=$ high $\mathrm{ED}$ close-up diet; $\mathrm{CON}=$ control lactation diet fed to meet lactation requirement during early lactation; TRT $=$ supplementation of $1.5 \mathrm{~kg} / \mathrm{d}$ ESB to CON during the first $4 \mathrm{wk}$ of lactation. Data are shown as least squares means and SEM $(\mathrm{A})$ Prepartum: ED, $P=0.009$; day, $P=0.15$; ED $\times$ day, $P=0.16$. Postpartum: ED, $P=0.51$; ESB, $P=0.14$; day, $P=0.003$; ED $\times \mathrm{ESB}, P=0.008 ; \mathrm{ED} \times$ day, $P<0.0001$; all other interactions, $P \geq 0.23$. (B) Prepartum: all main effects and interactions, $P \geq 0.46$. Postpartum: ED, $P=0.79$; ESB, $P=0.003$; day, $P$ $<0.0001 ; \mathrm{ED} \times \mathrm{ESB}, P=0.01 ; \mathrm{ED} \times$ day, $P=0.046$; ESB $\times$ day, $P=0.14$; ED $\times \mathrm{ESB} \times$ day, $P=0.02$. (C) Prepartum: ED, $P=0.56 ;$ day $P=0.02$; ED $\times$ day, $P=0.88$. Postpartum: ED, $P=0.58$; ESB, $P=0.11$; day, $P<0.0001 ; \mathrm{ED} \times \mathrm{ESB}, P=0.33 ; \mathrm{ED} \times$ day, $P=0.11 ; \mathrm{ESB}$ $\times$ day, $P=0.008 ; \mathrm{ED} \times \mathrm{ESB} \times$ day, $P=0.01$. 

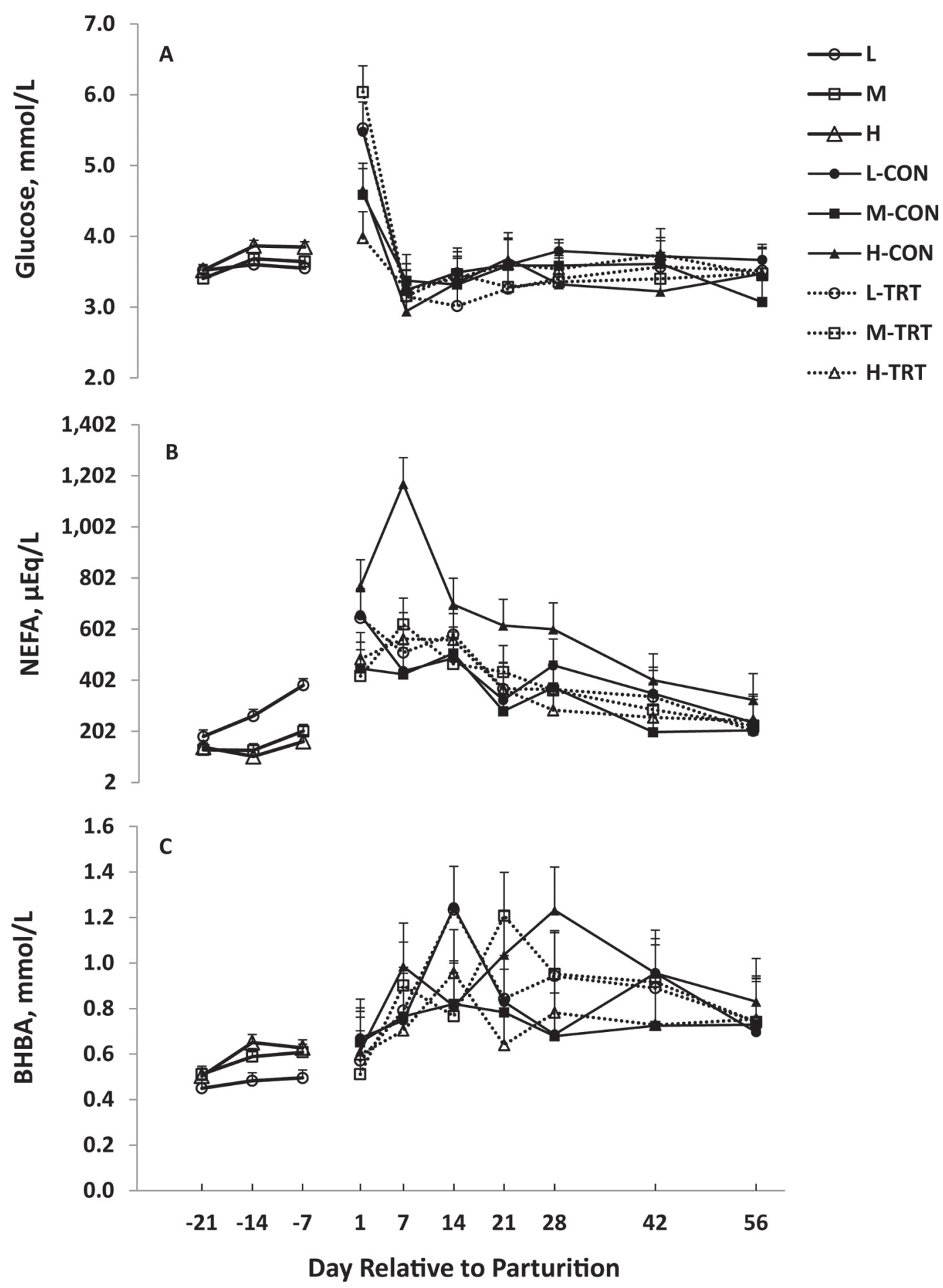

Figure 2. Effects of energy density (ED) in close-up diets and postpartum supplementation of extruded full-fat soybean (ESB) on blood glucose (A), NEFA (B), and BHBA (C) concentrations during the periparturient period. L = low ED close-up diet; $\mathrm{M}=$ medium ED close-up diet; $\mathrm{H}=$ high $\mathrm{ED}$ close-up diet; $\mathrm{CON}=$ control lactation diet fed to meet lactation requirement during early lactation; TRT $=$ supplementation of $1.5 \mathrm{~kg} / \mathrm{d}$ ESB to CON during the first 4 wk of lactation. Data are shown as least squares means and SEM (A) Prepartum: ED, $P=0.02$; day, $P<0.0001$; ED $\times$ day, $P=0.16$. Postpartum: day, $P<0.0001$; all other main effects and interactions, $P \geq 0.40$. (B) Prepartum: all main effects and interactions, $P<0.0001$. Postpartum: ED, $P=0.10$; ESB, $P=0.25$; day, $P<0.0001 ; \mathrm{ED} \times \mathrm{ESB}, P=0.06$; ED $\times$ day, $P=0.06$; ESB $\times$ day, $P=0.69 ; \mathrm{ED} \times \mathrm{ESB} \times$ day, $P=0.21$. $(\mathrm{C})$ Prepartum: ED, $P=0.006$; day, $P=0.0005 ; \mathrm{ED} \times$ day, $P=0.37$. Postpartum: day, $P$ $=0.004$; all other main effects and interactions, $P \geq 0.39$. 
Drackley, 2010). In other studies, greater loss in BW or BCS postpartum was also observed in cows overfed energy prepartum compared with those fed restricted energy intake prepartum (Agenäs et al., 2003; Dann et al., 2006; Hayirli et al., 2011). Magnitude of loss in BCS postpartum is associated with several factors, including BCS at calving and milk and milk fat yield (Broster and Broster, 1998). For example, cows with greater BCS at parturition lose more BCS postpartum compared with those in moderate or thinner condition (Broster and Broster, 1998). Cows with higher milk production often have greater loss in BCS (Waltner et al., 1993). In the present study, milk and milk fat production were not affected $(P>0.10)$ by prepartum ED. Therefore, the greater losses in BW and BCS were likely associated with the greater BCS in HED cows at parturition. Consistent with DMI, regardless of the large differences in prepartum EB, postpartum EB was similar $(P>0.10)$ among the 3 ED groups and all cows experienced negative EB in the first $4 \mathrm{wk}$ of lactation, which can be explained by the similar DMI, milk production, and BW (Figure 3). The lack of effect of prepartum DMI and energy intake on postpartum EB agreed with previous studies (Agenäs et al., 2003; Roche et al., 2005).

We observed no treatment effects for postpartum ESB supplementation $(P>0.10)$ on DMI, BW, change in BCS, or EB (Table 2, Figure 3), but $\mathrm{NE}_{\mathrm{I}}$ tended to increase $(P=0.09)$ with TRT during the first 8 wk of lactation due to the higher dietary $\mathrm{NE}_{\mathrm{L}}$ content (Table 2). Similarly, DMI was not influenced by supplemental ESB in a previous study (Annexstad et al., 1987). Block et al. (1981) reported that BW was not affected by feeding heat-treated soybean compared with unheated soybean during early lactation.

Lactation Responses. We detected no interaction $(P>0.10)$ between prepartum ED and postpartum ESB supplementation for any lactation variables (Table $3)$. No carryover effects $(P>0.10)$ of prepartum ED on milk yield and composition, or feed efficiency throughout the 8-wk lactation period were observed, although HED cows produced approximately $2 \mathrm{~kg} / \mathrm{d}$ less milk than did MED and LED cows (Table 3; Figure 4). Holcomb et al. (2001) also showed no effects of prepartum energy intake by either free choice or restricted feeding of high- or low-forage rations during the last 4 wk of gestation on postpartum milk yield. A lack of responses of milk yield and protein and lactose concentrations to prepartum feeding level were documented by other studies (Nielsen et al., 2003; Dann et al., 2006; Hayirli et al., 2011). The effect of prepartum feeding level on milk fat percentage has been inconsistent. Our observation is in agreement with the study of Rabelo et al. (2003), who found no effect of prepartum energy density on milk fat percentage in multiparous cows. In contrast, Janovick and Drackley (2010) indicated greater milk fat percentage in cows overfed compared with those with restricted fed, which was associated with greater BCS loss in overfed cows. In their study, however, the increased milk fat percentage was observed during the first 3 wk of lactation and did not carry over into the 8-wk lactation period. In the current study, the magnitude of BCS loss was the same in HED and LED cows during the first 4 wk of lactation, which may explain the lack of difference in milk fat percentage.

Supplementation of ESB in the TRT diet during the first 4 wk of lactation increased milk yield by $6.4 \%(P$ $=0.03)$, increased yield of lactose by $6.7 \%(P=0.04)$, increased yield of SNF by $6.6 \%(P=0.04)$, and tended to increase protein yield by $5.8 \%(P=0.09)$ without changing the concentrations of these variables compared with CON (Table 3; Figure 4). Milk fat percentage had a tendency to be decreased $5.7 \%(P=0.06)$ by TRT. No carryover effect $(P>0.10)$ of ESB on milk yield and composition was observed during wk 5 to 8 of lactation (Table 3). Extruded full-fat soybean has been previously used as an alternative protein source to replace soybean meal in the early-lactation diet and feeding as high as $23.7 \%$ (of TMR, DM basis) ESB significantly increased milk yield during the first $8 \mathrm{wk}$ of lactation (Chouinard et al., 1997). Feeding a diet containing $12 \%$ ESB to partially replace soybean meal also increased $3.5 \%$ FCM yield by $5.1 \mathrm{~kg} / \mathrm{d}$ in mid-lactation cows (Dhiman et al., 1999). Additionally, ESB has been used as a supplement for the lactation diet, and supplementation of $7 \%$ ESB increased milk production during early lactation (Smith et al., 1980). Our intention was to supplement ESB as a good source of both energy and protein to a typical diet used for early-lactation dairy cows in China. The increased milk yield in TRT group may be attributed to the increased dietary $\mathrm{NE}_{\mathrm{L}}$ contents and presumably increased proportions of undegradable protein by supplementation of ESB (Faldet and Satter, 1991). Indeed, diets containing ESB have been shown to have increased total EAA in the small intestine (Block et al., 1981; Stern et al., 1985), which was not measured in current experiment. Potential increases in total AA in the small intestine from ESB supplementation may subsequently provide more AA to the mammary gland and improve milk production. The decreased milk fat percentage in current study might be partially attributed to the dilution effect of increased milk volume or could be related to milk fat depression by ESB supplementation. Decreased milk fat content was observed when cows were fed ESB in diets low in fiber (Block et al., 1981; Schwab et al., 1980; Dhiman et al., 1999). In the study of Dhiman et al. (1999), the cause of milk fat depression by ESB was attributed to 

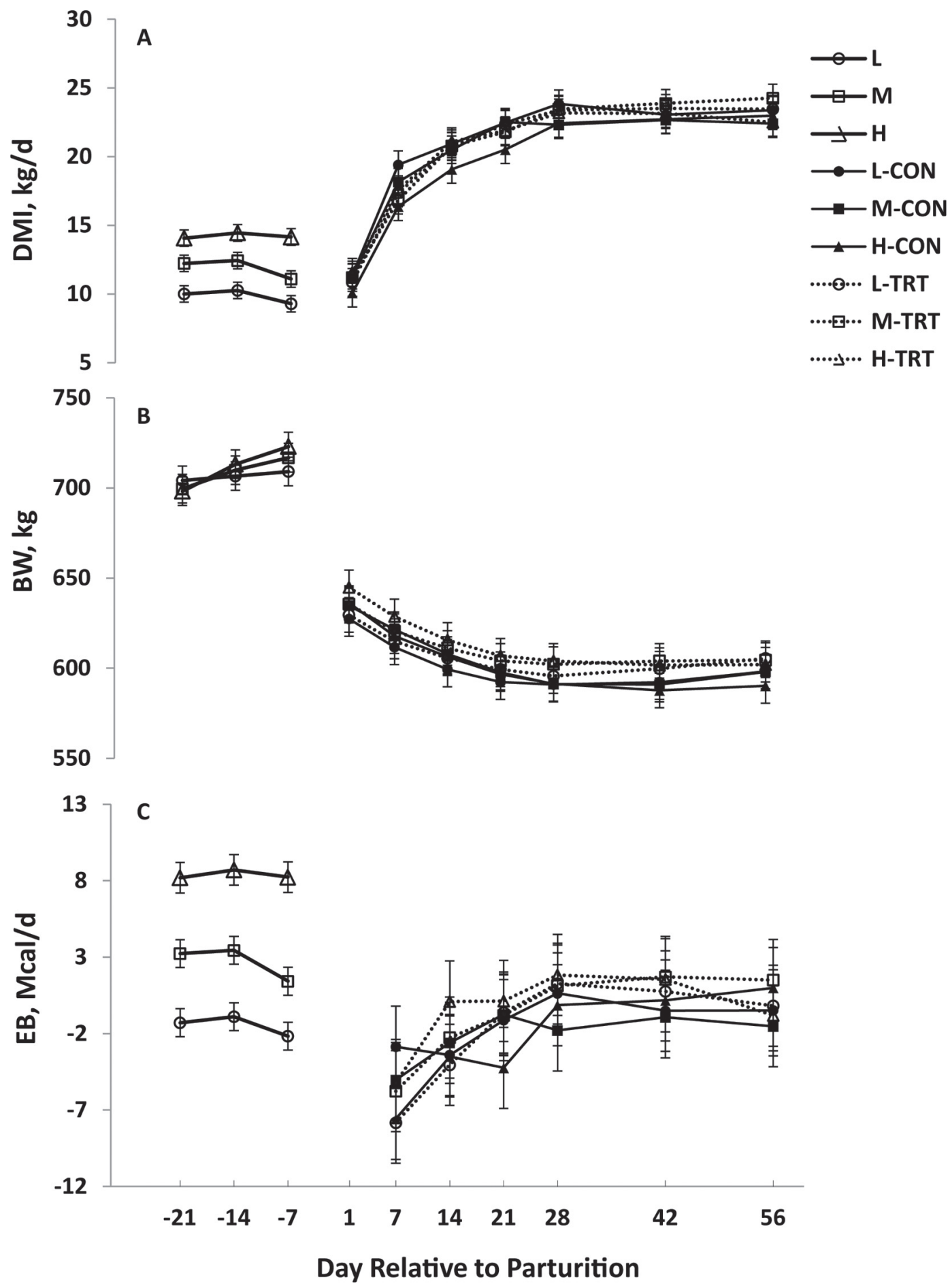

Figure 3. Effects of energy density (ED) in close-up diets and postpartum supplementation of extruded full-fat soybean (ESB) on DMI (A), BW (B), and EB (C) during the periparturient period. L = low ED close-up diet; $\mathrm{M}=$ medium ED close-up diet; $\mathrm{H}=$ high ED close-up diet; $\mathrm{CON}=$ control lactation diet fed to meet lactation requirement during early lactation; TRT $=$ supplementation of $1.5 \mathrm{~kg} / \mathrm{d}$ ESB to CON during the first 4 wk of lactation. Data are shown as least squares means and SEM (A) Prepartum: ED, $P<0.0001 ;$ day, $P=0.04 ;$ ED $\times$ day, $P=$ 0.68. Postpartum: day, $P<0.0001$; all other main effects and interactions, $P \geq 0.40$. (B) Prepartum: ED, $P<0.91$; day, $P<0.0001$; ED $\times$ day, $P=0.0004$. Postpartum: ED, $P=0.89$; ESB, $P=0.34$; day, $P<0.0001$; ED $\times$ day, $P=0.001$; all other interactions, $P \geq 0.32$. (C) Prepartum: ED, $P<0.0001$; day, $P=0.0495$; ED $\times$ day, $P=0.67$. Postpartum: day, $P=0.0005$; all other main effects and interactions, $P \geq 0.36$. 
PREPARTUM ENERGY LEVEL AND POSTPARTUM SOYBEAN FEEDING

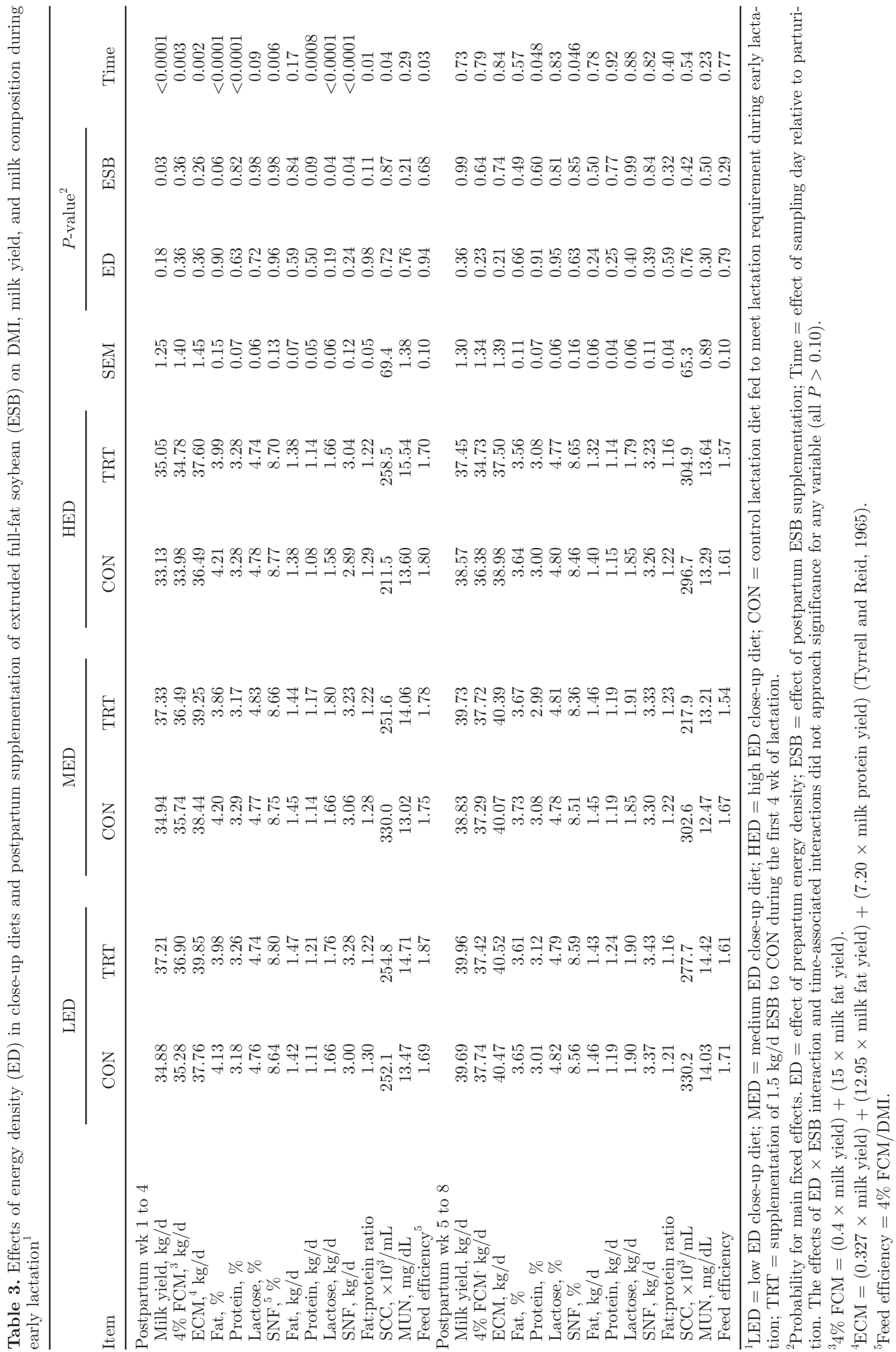



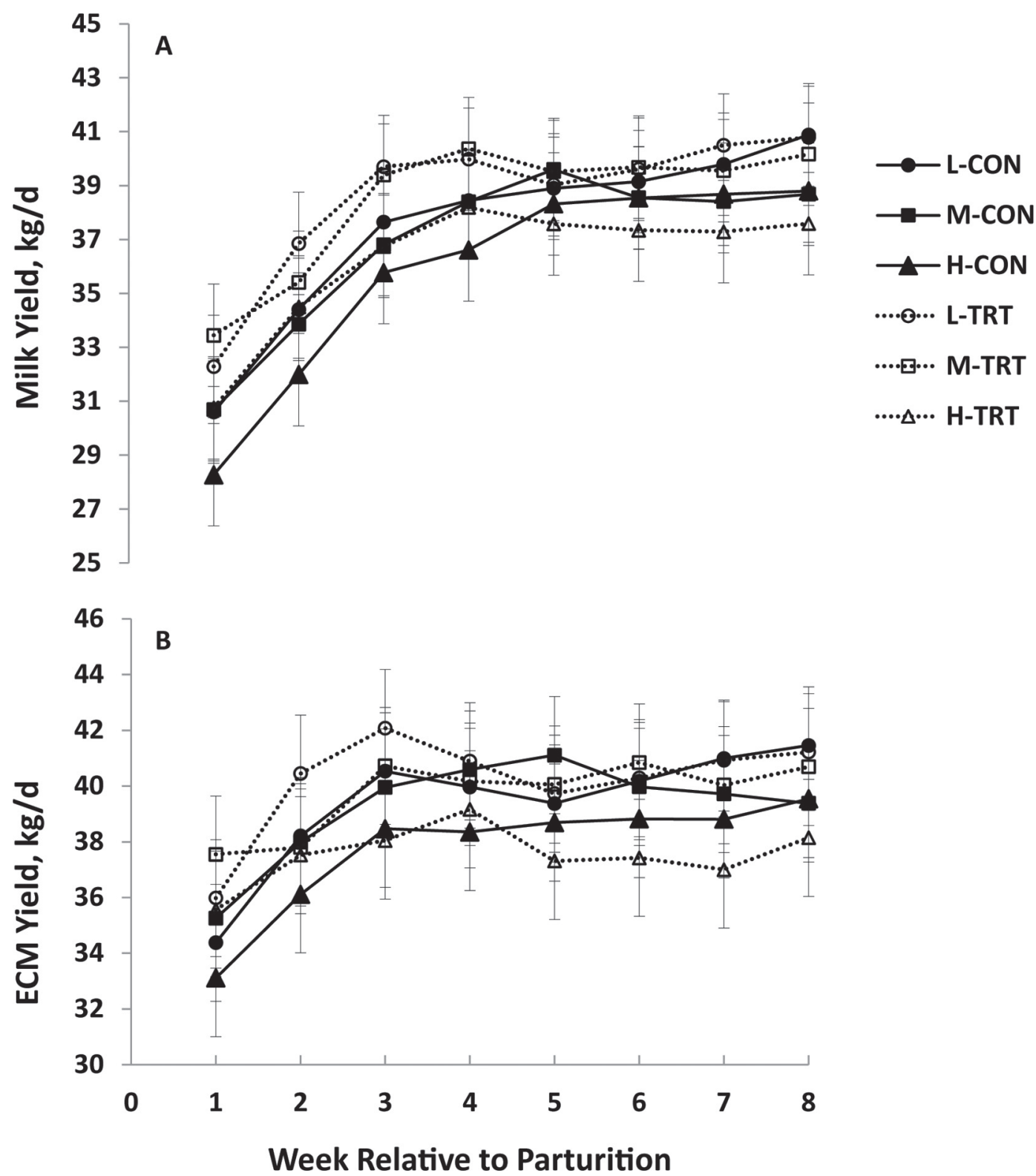

Figure 4. Effects of energy density (ED) in close-up diets and postpartum supplementation of extruded full-fat soybean (ESB) on milk yield (A) and ECM yield (B) during early lactation. $\mathrm{L}=$ low ED close-up diet; $\mathrm{M}=$ medium ED close-up diet; $\mathrm{H}=$ high ED close-up diet; CON = control lactation diet fed to meet lactation requirement during early lactation; TRT $=$ supplementation of $1.5 \mathrm{~kg} / \mathrm{d}$ ESB to CON during the first 4 wk of lactation. Data are shown as least squares means and SEM (A) wk 1 to 4 : ED, $P=0.19 ; \mathrm{ESB}, P=0.03$; day, $P<0.0001$; all interactions, $P \geq 0.98$; wk 5 to 8: all main effects and interactions, $P \geq 0.36$; (B) wk 1 to 4: $\mathrm{ED}, P=0.36$; ESB, $P=0.27$; day, $P=0.002$; all interactions, $P \geq 0.90$; wk 5 to 8 : all main effects and interactions, $P \geq 0.36$.

its high contents of total FA, particularly C18:2, which can be converted to C18:1 via rumen biohydrogenation. One trans isomer of C18:1 fatty acid can cause milk fat depression (Romo et al., 1996).

Blood Hormones and Metabolites. We detected no interaction $(P>0.10)$ between prepartum ED and postpartum ESB supplementation for blood concentrations of glucose, BHBA, triglyceride, BUN, or cholesterol (Table 4). Prepartum ED did not affect $(P>$
0.10) blood glucose concentrations during early lactation (Table 4). All cows experienced a striking increase in blood glucose concentration at calving and then maintained low glucose concentrations during early lactation, which has been demonstrated by many others (Vazquez-Anon et al., 1994; Dann et al., 1999; Hayirli et al., 2011). We found an interaction between ED and time for insulin concentration during the first $8 \mathrm{wk}$ of lactation $(P<0.01$; Table 4$)$. Compared with LED and 
PREPARTUM ENERGY LEVEL AND POSTPARTUM SOYBEAN FEEDING

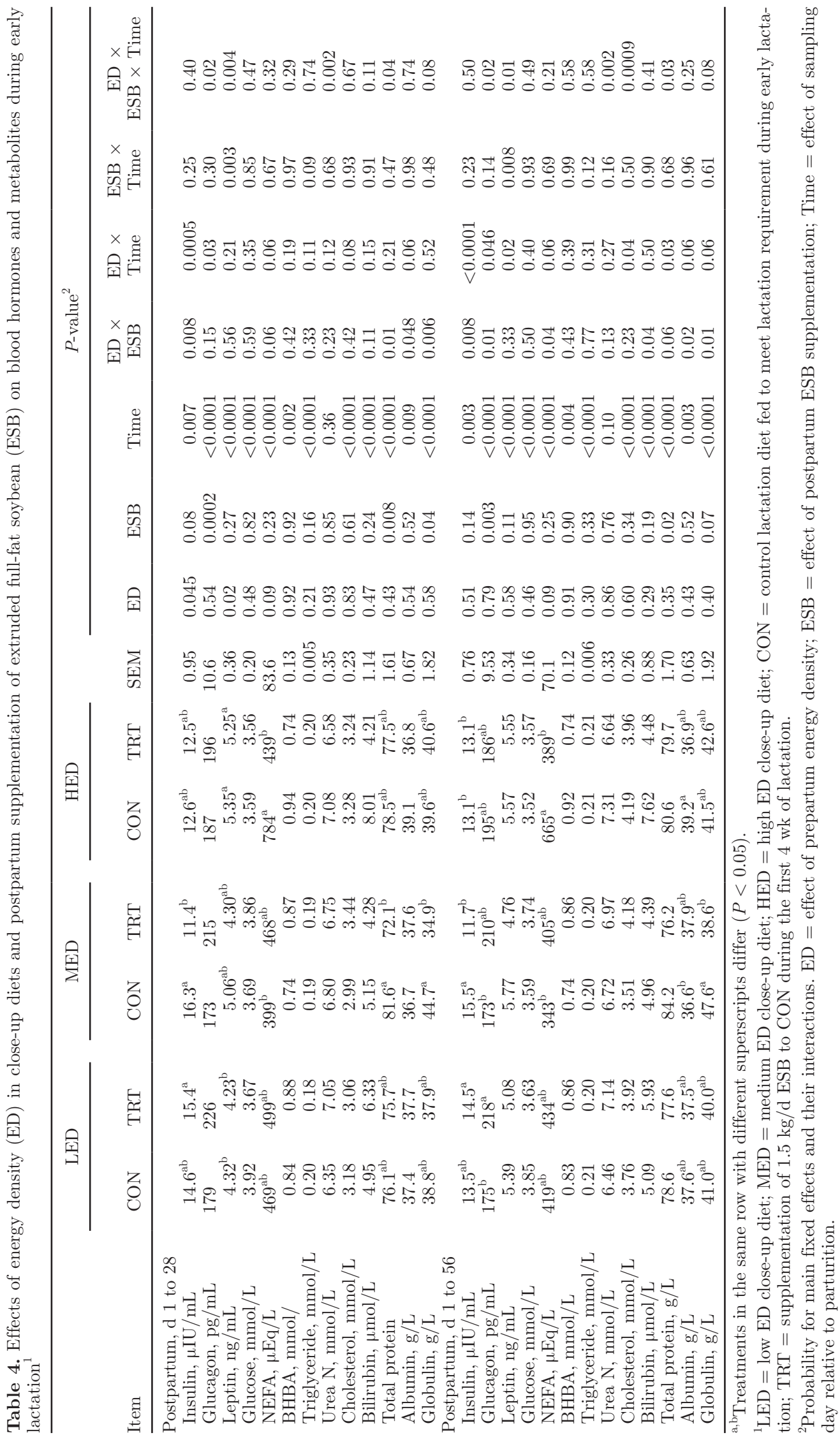


MED cows, HED cows tended to have lower $(0.05<P$ $<0.10)$ insulin concentration at $14 \mathrm{~d}$ relative to parturition (Figure 1). Both HED cows and MED cows, but not LED cows, had a reduction of insulin concentration at $1 \mathrm{~d}$ after parturition, which paralleled the peak of glucose concentration. The HED cows then maintained low insulin concentrations until 8 wk of lactation, and the LED and MED cows had a higher level of insulin for about 2 to $3 \mathrm{wk}$ before the level decreased to that of HED cows (Figure 1). As DMI and EB status increased during early lactation, leptin exhibited an overall trend of increase except for a large spike at $7 \mathrm{~d}$ after calving (Figure 1). Compared with LED cows, HED cows had higher $(P<0.05)$ leptin concentrations during the first 4 wk of lactation (Table 4; Figure 1), which was not related to a higher BCS, as suggested by Janovick et al. (2011). Holtenius et al. (2003) also suggested that leptin was not related to BCS in postparturient cows.

We observed no effect $(P>0.10)$ of ESB supplementation on blood concentrations of glucose, BHBA, triglyceride, BUN, or cholesterol (Table 4). There was an interaction between ESB and time for blood leptin concentration during the first 4 wh of lactation $(P=$ 0.003; Table 4; Figure 1). The TRT diet reduced leptin concentrations at $7 \mathrm{~d}$ relative to parturition compared with CON $(P=0.009$; Figure 1$)$. Decreased leptin could benefit dairy cattle by alleviating feed depression. Postpartum ESB supplementation elevated blood glucagon concentration regardless of prepartum ED during the first 4 wk of lactation $(P=0.0002)$, and an interaction between prepartum ED, postpartum ESB, and time was observed on glucagon concentration during the first 8 wk of lactation $(P<0.05$; Table 4). Postpartum ESB supplementation elevated $(P<$ $0.05)$ glucagon concentration for LED cows throughout the first 8 wk of lactation and for MED cows at $14 \mathrm{~d}$ relative to parturition (Table 4; Figure 1). Glucagon promotes gluconeogenesis and increases the mRNA expression of gluconeogenic enzymes in liver of early lactating cows (Bobe et al., 2009), and it is used to prevent or treat fatty liver disease in dairy cattle (Bobe et al., 2003; Nafikov et al., 2006). The increased glucagon concentration in cows receiving the TRT diet indicated an improved gluconeogenic status and may be related to the increased production of milk and lactose.

An interaction between ED and ESB supplementation was detected $(P<0.05)$ for concentrations of insulin and NEFA during the first 8 wk of lactation (Table 4). The TRT diet decreased $(P<0.05)$ blood insulin and NEFA concentrations for MED and HED cows, respectively (Table 4). The decreased NEFA concentration in the TRT group was not likely a result of decreased mobilization of body fat because of the lack of differences in change in BCS between the
CON and TRT groups. Therefore, it might be because of increased utilization of NEFA by the liver of the TRT cows. There were also interactions between prepartum ED and postpartum ESB supplementation for the concentrations of bilirubin, total protein, albumin, and globulin $(P<0.05$; Table 4$)$. For cows receiving the HED diet prepartum, the TRT diet reduced their blood bilirubin concentration, indicating improved liver function (Bertoni et al., 2008). For cows receiving the MED diet prepartum, the TRT diet decreased globulin concentration (34.91 vs. $44.65 \mathrm{~g} / \mathrm{L}$ ) throughout the 8 wk of lactation, accompanied by decreased total protein during the first $4 \mathrm{wk}$ of lactation (Table 4). Blood globulin can be used as an indicator of positive acute phase protein synthesis induced by cytokines in liver, and cows with a higher concentration of globulin (42.5 vs. $39.0 \mathrm{~g} / \mathrm{L}$ ) have more severe inflammatory status and impaired liver function and more-pronounced negative EB during the first month of lactation (Bertoni et al., 2008). Therefore, from the standpoint of metabolic status and liver function, supplemental ESB is beneficial to cows in early lactation, especially for those receiving MED and HED diets prepartum.

\section{CONCLUSIONS}

Ad libitum feeding of the HED diet during close-up period impaired metabolic status during early lactation, as reflected by higher plasma NEFA level and greater loss of BW and BCS compared with the LED and MED diets. Supplementation of ESB during the first $4 \mathrm{wk}$ of lactation increased milk yield regardless of prepartum ED. An interaction between prepartum ED and postpartum ESB supplementation was observed for blood NEFA and bilirubin concentrations during early lactation. Supplementation of ESB improved postpartum metabolic status and liver function for cows that were overfed prepartum.

\section{ACKNOWLEDGMENTS}

This work was supported by the National Natural Science Foundation of China (Beijing, China; Grant No. 31272469) and the earmarked fund for National Dairy Industry and Technology System (Beijing, China; CARS-37). The authors acknowledge Runmin Dairy Farm (Beijing, China) for providing the experimental conditions and experimental animals.

\section{REFERENCES}

Agenäs, S., E. Burstedt, and K. Holtenius. 2003. Effects of feeding intensity during the dry period. 1. Feed intake, body weight, and milk production. J. Dairy Sci. 86:870-882. 
Annexstad, R. J., M. D. Stern, D. E. Otterby, J. G. Linn, and W. P. Hansen. 1987. Extruded soybeans and corn gluten meal as supplemental protein sources for lactating dairy cattle. J. Dairy Sci. $70: 814-822$.

AOAC International. 2000. Official Methods of Analysis. 17th ed. AOAC International, Gaithersburg, MD.

Baracos, V. E., J. Brun-Bellut, and M. Marie. 1991. Tissue protein synthesis in lactating and dry goats. Br. J. Nutr. 66:451-465.

Beever, D. E. 2006. The impact of controlled nutrition during the dry period on dairy cow health, fertility and performance. Anim. Reprod. Sci. 96:212-226.

Bell, A. W. 1995. Regulation of organic nutrient metabolism during transition from late pregnancy to early lactation. J. Anim. Sci. $73: 2804-2819$

Bertoni, G., E. Trevisi, X. Han, and M. Bionaz. 2008. Effects of inflammatory conditions on liver activity in puerperium period and consequences for performance in dairy cows. J. Dairy Sci. 91:3300-3310.

Block, E., L. D. Muller, L. C. Griel Jr., and D. L. Garwood. 1981. Brown midrib-3 corn silage and heat extruded soybeans for early lactating dairy cows. J. Dairy Sci. 64:1813-1825.

Block, S. S., W. R. Butler, R. A. Ehrhardt, A. W. Bell, M. E. Van Amburgh, and Y. R. Boisclair. 2001. Decreased concentration of plasma leptin in periparturient dairy cows is caused by negative energy balance. J. Endocrinol. 171:339-348.

Bobe, G., B. N. Ametaj, J. W. Young, and D. C. Beitz. 2003. Potential treatment of fatty liver with 14-day subcutaneous injections of glucagon. J. Dairy Sci. 86:3138-3147.

Bobe, G., J. C. Velez, D. C. Beitz, and S. S. Donkin. 2009. Glucagon increases hepatic mRNA concentrations of ureagenic and gluconeogenic enzymes in early-lactation dairy cows. J. Dairy Sci. 92:5092-5099

Broster, W. H., and V. J. Broster. 1998. Body score of dairy cows. J. Dairy Res. 65:155-173.

Chouinard, P. Y., J. Lévesque, V. Girard, and G. J. Brisson. 1997. Dietary soybeans extruded at different temperatures: milk composition and in situ fatty acid reactions. J. Dairy Sci. 80:2913-2924.

Dann, H. M., N. B. Litherland, J. P. Underwood, M. Bionaz, A. D'Angelo, J. W. McFadden, and J. K. Drackley. 2006. Diets during far-off and close-up dry periods affect periparturient metabolism and lactation in multiparous cows. J. Dairy Sci. 89:3563-3577.

Dann, H. M., G. A. Varga, and D. E. Putnam. 1999. Improving energy supply to late gestation and early postpartum dairy cows. J. Dairy Sci. 82:1765-1778.

Delavaud, C., F. Bocquier, Y. Chilliard, D. H. Keisler, A. Gertler, and G. Kann. 2000. Plasma leptin determination in ruminants: Effect of nutritional status and body fatness on plasma leptin concentration assessed by a specific RIA in sheep. J. Endocrinol. 165:519-526.

Delavaud, C., A. Ferlay, Y. Faulconnier, F. Bocquier, G. Kann, and Y. Chilliard. 2002. Plasma leptin concentration in adult cattle: Effects of breed, adiposity, feeding level, and meal intake. J. Anim. Sci. 80:1317-1328.

Dhiman, T. R., E. D. Helmink, D. J. McMahon, R. L. Fife, and M. W. Pariza. 1999. Conjugated linoleic acid content of milk and cheese from cows fed extruded oilseeds. J. Dairy Sci. 82:412-419.

Douglas, G. N., T. R. Overton, H. G. Bateman Ii, H. M. Dann, and J. K. Drackley. 2006. Prepartal plane of nutrition, regardless of dietary energy source, affects periparturient metabolism and dry matter intake in Holstein cows. J. Dairy Sci. 89:2141-2157.

Drackley, J. K. 1999. Biology of dairy cows during the transition period: The final frontier? J. Dairy Sci. 82:2259-2273.

Ekinci, C., and G. A. Broderick. 1997. Effect of processing high moisture ear corn on ruminal fermentation and milk yield. J. Dairy Sci. 80:3298-3307.

Faldet, M. A., and L. D. Satter. 1991. Feeding heat-treated full fat soybeans to cows in early lactation. J. Dairy Sci. 74:3047-3054.

FASS. 2010. Guide for the Care and Use of Agricultural Animals in Research and Teaching. 3rd ed. FASS (Federation of Animal Science Societies), Champaign, IL.
Goff, J. P., and R. L. Horst. 1997. Physiological changes at parturition and their relationship to metabolic disorders. J. Dairy Sci. 80:1260-1268.

Grummer, R. R. 1995. Impact of changes in organic nutrient metabolism on feeding the transition dairy cow. J. Anim. Sci. 73:28202833.

Hayirli, A. 2006. The role of exogenous insulin in the complex of hepatic lipidosis and ketosis associated with insulin resistance phenomenon in postpartum dairy cattle. Vet. Res. Commun. 30:749-774.

Hayirli, A., D. H. Keisler, and L. Doepel. 2011. Peripartum responses of dairy cows to prepartal feeding level and dietary fatty acid source. J. Dairy Sci. 94:917-930.

Holcomb, C. S., H. H. Van Horn, H. H. Head, M. B. Hall, and C. J. Wilcox. 2001. Effects of prepartum dry matter intake and forage percentage on postpartum performance of lactating dairy cows. J. Dairy Sci. 84:2051-2058.

Holtenius, K., S. Agenäs, C. Delavaud, and Y. Chilliard. 2003. Effects of feeding intensity during the dry period. 2. Metabolic and hormonal responses. J. Dairy Sci. 86:883-891.

Janovick, N. A., Y. R. Boisclair, and J. K. Drackley. 2011. Prepartum dietary energy intake affects metabolism and health during the periparturient period in primiparous and multiparous Holstein cows. J. Dairy Sci. 94:1385-1400.

Janovick, N. A., and J. K. Drackley. 2010. Prepartum dietary management of energy intake affects postpartum intake and lactation performance by primiparous and multiparous Holstein cows. J. Dairy Sci. 93:3086-3102.

Kadokawa, H., D. Blache, Y. Yamada, and G. B. Martin. 2000. Relationships between changes in plasma concentrations of leptin before and after parturition and the timing of first post-partum ovulation in high-producing Holstein dairy cows. Reprod. Fertil. Dev. 12:405-411.

LeBlanc, S. J., K. D. Lissemore, D. F. Kelton, T. F. Duffield, and K. E. Leslie. 2006. Major advances in disease prevention in dairy cattle. J. Dairy Sci. 89:1267-1279.

Liefers, S. C., R. F. Veerkamp, M. F. W. Te Pas, C. Delavaud, Y. Chilliard, and T. Van der Lende. 2003. Leptin concentrations in relation to energy balance, milk yield, intake, live weight, and estrus in dairy cows. J. Dairy Sci. 86:799-807.

Mashek, D. G., and D. K. Beede. 2001. Peripartum responses of dairy cows fed energy-dense diets for 3 or 6 weeks prepartum. J. Dairy Sci. 84:115-125.

Mielke, C. D., and D. J. Schingoethe. 1981. Heat-treated soybeans for lactating cows. J. Dairy Sci. 64:1579-1585.

Nafikov, R. A., B. N. Ametaj, G. Bobe, K. J. Koehler, J. W. Young, and D. C. Beitz. 2006. Prevention of fatty liver in transition dairy cows by subcutaneous injections of glucagon. J. Dairy Sci. 89:1533-1545.

Nielsen, N. I., K. L. Ingvartsen, and T. Larsen. 2003. Diurnal variation and the effect of feed restriction on plasma and milk metabolites in TMR-fed dairy cows. J. Vet. Med. A Physiol. Pathol. Clin. Med. 50:88-97.

NRC. 2001. Nutrient Requirements of Dairy Cattle. 7th rev. ed. Natl. Acad. Sci., Washington, DC.

Ospina, P. A., D. V. Nydam, T. Stokol, and T. R. Overton. 2010 Evaluation of nonesterified fatty acids and $\beta$-hydroxybutyrate in transition dairy cattle in the northeastern United States: Critical thresholds for prediction of clinical diseases. J. Dairy Sci. 93:546-554.

Rabelo, E., S. J. Bertics, J. Mackovic, and R. R. Grummer. 2001. Strategies for increasing energy density of dry cow diets. J. Dairy Sci. 84:2240-2249.

Rabelo, E., R. L. Rezende, S. J. Bertics, and R. R. Grummer. 2003. Effects of transition diets varying in dietary energy density on lactation performance and ruminal parameters of dairy cows. J. Dairy Sci. 86:916-925.

Reist, M., D. Erdin, D. Von Euw, K. Tschuemperlin, H. Leuenberger, C. Delavaud, Y. Chilliard, H. M. Hammon, N. Kuenzi, and J. W. Blum. 2003. Concentrate feeding strategy in lactating dairy cows: Metabolic and endocrine changes with emphasis on leptin. J. Dairy Sci. 86:1690-1706. 
Roche, J. R., E. S. Kolver, and J. K. Kay. 2005. Influence of precalving feed allowance on periparturient metabolic and hormonal responses and milk production in grazing dairy cows. J. Dairy Sci. 88:677-689.

Romo, G. A., D. P. Casper, R. A. Erdman, and B. B. Teter. 1996. Abomasal infusion of cis or trans fatty acid isomers and energy metabolism of lactating dairy cows. J. Dairy Sci. 79:2005-2015.

Ruegsegger, G. J., and L. H. Schultz. 1985. Response of high producing dairy cows in early lactation to the feeding of heat-treated whole soybeans. J. Dairy Sci. 68:3272-3279.

Schwab, C. G., S. J. Muise, and J. B. Holter. 1980. The effect of extruded heat-processed soybeans and methionine on performance, nitrogen and energy metabolism and blood parameters in early lactation cows. J. Dairy Sci. 63(Suppl. 1):140. (Abstr.)

Smith, N. E., L. S. Collar, D. L. Bath, W. L. Dunkley, and A. A. Franke. 1980. Whole cottonseed and extruded soybean for cows in early lactation. J. Dairy Sci. 63(Suppl. 1):153-154.

Stern, M. D., K. A. Santos, and L. D. Satter. 1985. Protein degradation in rumen and amino acid absorption in small intestine of lactating dairy cattle fed heat-treated whole soybeans. J. Dairy Sci. 68:45-56.

Tyrrell, H. F., and J. T. Reid. 1965. Prediction of the energy value of cow's milk. J. Dairy Sci. 48:1215-1223.

Van Soest, P. J., J. B. Robertson, and B. A. Lewis. 1991. Methods for dietary fiber, neutral detergent fiber, and non-starch polysaccharides in relation to animal nutrition. J. Dairy Sci. 74:3583-3597.
Vandehaar, M. J., G. Yousif, B. K. Sharma, T. H. Herdt, R. S. Emery, M. S. Allen, and J. S. Liesman. 1999. Effect of energy and protein density of prepartum diets on fat and protein metabolism of dairy cattle in the periparturient period. J. Dairy Sci. 82:1282-1295.

Vazquez-Anon, M., S. Bertics, M. Luck, R. R. Grummer, and J. Pinheiro. 1994. Peripartum liver triglyceride and plasma metabolites in dairy cows. J. Dairy Sci. 77:1521-1528.

Vickers, L. A., D. M. Weary, D. M. Veira, and M. A. G. von Keyserlingk. 2013. Feeding a higher forage diet prepartum decreases incidences of subclinical ketosis in transition dairy cows. J. Anim. Sci. 91:886-894.

Waltner, S. S., J. P. McNamara, and J. K. Hillers. 1993. Relationships of body condition score to production variables in high producing Holstein dairy cattle. J. Dairy Sci. 76:3410-3419.

Wildman, E. E., G. M. Jones, P. E. Wagner, R. L. Boman, H. F. Troutt, and T. N. Lesch. 1982. A dairy cow body condition scoring system and its relationship to selected production characteristics. J. Dairy Sci. 65:495-501.

Winkelman, L. A., T. H. Elsasser, and C. K. Reynolds. 2008. Limitfeeding a high-energy diet to meet energy requirements in the dry period alters plasma metabolite concentrations but does not affect intake or milk production in early lactation. J. Dairy Sci 91:1067-1079. 